\title{
Risk Factors for Incisional Hernia and Parastomal Hernia after Colorectal Surgery
}

\author{
Byung-Kwon Ahn \\ Department of Surgery, Kosin University College of Medicine, Busan, Korea
}

See Article on Page 299-303

Incisional hernias, with an incidence of 9 to $38 \%$, remain one of the most common complications after an incision of the abdominal wall [1-3]. An incisional hernia is defined as a protrusion of intraperitoneal structures through a defect in the anterior abdominal wall fascia [4]. This means that wound healing often fails to occur when multiple predisposing factors, including surgical site infection, malnutrition, diabetes, immunosuppression, and morbid obesity, are present [5].

Incisional hernias are almost universally regarded as technical failures. Technical factors are related to suture material selection, type of fascial closure, ratio of suture to incision length [5]. In spite of many advances, such as new procedures for closing the abdominal wall and new suture materials, the incidence of incisional hernias has not been reduced in recent decades because the developments of incisional hernias is also related to many factors affecting the patients.

Surgical site infection is one of the important risk factors for the development of an incisional hernia. Recently, Murray et al. [6] analyzed the incidence of incisional hernias related with surgical site infection in colorectal surgery. They reported that patients with a surgical site infection were 1.9 times more likely to have an incisional hernia than those without a surgical site infection ( $36.3 \%$ vs. $18.8 \%, \mathrm{P} \leq 0.01)$. In clean-contaminated and contaminated surgery, such as colorectal surgery, the incidence of surgical site infection has been reported as 3 to $30 \%[7,8]$. Thus, in colorectal surgery, more effort to prevent surgical site infection is needed.

Correspondence to: Byung-Kwon Ahn, M.D.

Department of Surgery, Kosin University College of Medicine,

262 Gamcheon-ro, Seo-gu, Busan 602-702, Korea

Tel: +82-51-990-6462, Fax: +82-51-246-6093

E-mail:gsabk@hotmail.com

(C) 2012 The Korean Society of Coloproctology

This is an open-access article distributed under the terms of the Creative Commons Attribution NonCommercial License (http://creativecommons.org/licenses/by-nc/3.0) which permits unrestricted noncommercial use, distribution, and reproduction in any medium, provided the original work is properly cited.
Morbid obesity is another important risk factor for the development of an incisional hernia and a parastomal hernia $[9,10]$. Schreinemacher et al. [9] reported that hernias were more prevalent in patients with morbid obesity (body mass index of 30 and higher) and in patients with a temporary stoma wound (25.8\% vs. $59.1 \%)$. De Raet et al. [10] reported that a waist circumference in excess of $100 \mathrm{~cm}$ increased the risk of developing a parastomal hernia (odds ratio, 1.009; 95\% confidence interval, 1.002 to 1.016).

Other factors, such as anemia, hypoproteinemia, malnutrition, diabetes, immunosuppression, male gender, and old age, are related to surgical wound dehiscence and incisional hernias [11]. Conditions that increase abdominal pressure, such as coughing, vomiting, distention, and ascites, also increase the incidence of incisional hernias. Surgeons have to be aware of poor wound healing conditions to prevent incisional hernias. Perioperative efforts to reduce risk factors and to select proper technical methods of wound closure are essential if the incidence of incisional hernias is to be reduced.

\section{REFERENCES}

1. Holland AJ, Castleden WM, Norman PE, Stacey MC. Incisional hernias are more common in aneurysmal arterial disease. Eur J Vasc Endovasc Surg 1996;12:196-200.

2. Mudge M, Hughes LE. Incisional hernia: a 10 year prospective study of incidence and attitudes. Br J Surg 1985;72:70-1.

3. Sugerman HJ, Kellum JM Jr, Reines HD, DeMaria EJ, Newsome $\mathrm{HH}$, Lowry JW. Greater risk of incisional hernia with morbidly obese than steroid-dependent patients and low recurrence with prefascial polypropylene mesh. Am J Surg 1996;171:80-4.

4. Korenkov M, Paul A, Sauerland S, Neugebauer E, Arndt M, Chevrel JP, et al. Classification and surgical treatment of incisional hernia. Results of an experts' meeting. Langenbecks Arch Surg 2001;386: 65-73.

5. Veljkovic R, Protic M, Gluhovic A, Potic Z, Milosevic Z, Stojadinovic A. Prospective clinical trial of factors predicting the early development of incisional hernia after midline laparotomy. J Am Coll Surg 2010;210:210-9. 
6. Murray BW, Cipher DJ, Pham T, Anthony T. The impact of surgical site infection on the development of incisional hernia and small bowel obstruction in colorectal surgery. Am J Surg 2011; 202:558-60.

7. Tang R, Chen HH, Wang YL, Changchien CR, Chen JS, Hsu KC, et al. Risk factors for surgical site infection after elective resection of the colon and rectum: a single-center prospective study of 2,809 consecutive patients. Ann Surg 2001;234:181-9.

8. Smith RL, Bohl JK, McElearney ST, Friel CM, Barclay MM, Sawyer RG, et al. Wound infection after elective colorectal resection. Ann Surg 2004;239:599-605.
9. Schreinemacher MH, Vijgen GH, Dagnelie PC, Bloemen JG, Huizinga BF, Bouvy ND. Incisional hernias in temporary stoma wounds: a cohort study. Arch Surg 2011;146:94-9.

10. De Raet J, Delvaux G, Haentjens P, Van Nieuwenhove Y. Waist circumference is an independent risk factor for the development of parastomal hernia after permanent colostomy. Dis Colon Rectum 2008;51:1806-9.

11. Sorensen LT, Hemmingsen U, Kallehave F, Wille-Jorgensen P, Kjaergaard J, Moller LN, et al. Risk factors for tissue and wound complications in gastrointestinal surgery. Ann Surg 2005;241: 654-8. 